Binghamton University

The Open Repository @ Binghamton (The ORB)

7-10-2018

\title{
Multilevel Governance: Framing the Integration of Top-Down and Bottom-Up Policymaking
}

\author{
George C. Homsy \\ Binghamton University--SUNY, ghomsy@binghamton.edu \\ Zhilin Liu \\ Tsinghua University \\ Mildred E. Warner \\ Cornell University, mwarner@cornell.edu
}

Follow this and additional works at: https://orb.binghamton.edu/public_admin_fac

Part of the Public Administration Commons

\section{Recommended Citation}

Homsy, George C.; Liu, Zhilin; and Warner, Mildred E., "Multilevel Governance: Framing the Integration of Top-Down and Bottom-Up Policymaking" (2018). Public Administration Faculty Scholarship. 45.

https://orb.binghamton.edu/public_admin_fac/45

This Article is brought to you for free and open access by the Public Administration at The Open Repository @ Binghamton (The ORB). It has been accepted for inclusion in Public Administration Faculty Scholarship by an authorized administrator of The Open Repository @ Binghamton (The ORB). For more information, please contact ORB@binghamton.edu. 


\title{
Multilevel Governance: Framing the Integration of Top-Down and Bottom-Up Policymaking
}

\begin{abstract}
Scholars embrace multilevel governance as an analytical framework for complex problems, such as climate change or water pollution. However, the elements needed to comprehensively operationalize multilevel governance remain undefined in the literature. This paper describes the five necessary ingredients to a multilevel framework: sanctioning and coordinating authority, provision of capacity, knowledge co-production, framing of co-benefits, and inclusion of civil society. The framework's analytical utility is illustrated through two contrasting case examples - watershed management in the U.S. and air quality management in China. The framework balances local and central actors, which can promote a more effective governance regime.
\end{abstract}

Keywords: multilevel governance, sustainability, environmental protection, United States, China 


\section{Introduction}

Environmental sustainability is a complex problem for national and local governments around the world. Sustainability policymaking challenges traditional governance models that focus on single issues confined within geographic or bureaucratic silos (Kettl, 2002). At the intersection of environmental, social, and economic issues, sustainability points to a multidimensional, cross-jurisdictional, and long-term view of development that public administration in all countries must address (Fiorino, 2010).

Multilevel governance has emerged as a framework for analyzing environmental sustainability and other regional or commons challenges (Balme \& Qi, 2014; Bulkeley, 2010; Homsy \& Warner, 2013). Multilevel governance sits in contrast to a decentralized, polycentric approach that celebrates local action (Nagendra \& Ostrom, 2012; Ostrom, 2010a; Sovacool, 2011) or a top-down, hierarchical approach that privileges central control (Andrews, 2006; Stavins, 2010). While cities may initiate environmental protection, they must coordinate in a multilevel manner with each other, with regional or national governments, and with other nonstate actors to be successful (Bulkeley \& Betsill, 2005). Cities operate within complex governance systems and variations in local government outcomes may result from external factors, such as connections with non-governmental organizations and support from a central authority (Andersson \& Ostrom, 2008).

Missing from the literature is a comprehensive conceptualization of a multilevel governance framework that tracks the various complex interactions (Caponio \& Jones-Correa, 2017). Existing studies typically focus on individual components of multilevel governance. For example, some emphasize the nested nature of multilevel governance in which cities interact with higher levels of government (Dale, Burch, Robinson, \& Strashok, 2018; H. Li \& Yi, 2014). 
Other scholars stress the horizontal interaction between cities and with the engagement of nonstate actors to allow co-production of knowledge and policy (Homsy \& Warner, 2013). Still others focus on the instances of interdependencies between stakeholders, whether or not they can impact policy outcomes (Alcantara \& Nelles, 2014).

The theoretical contribution of this paper is an examination of the manner in which various components of multilevel governance integrate to produce policy. This paper lays out a framework consisting of five interrelated parts: sanctioning and coordinating authority, provision of capacity, knowledge co-production, framing of co-benefits, and inclusion of civil society. Two environmental cases in radically different political and institutional contexts - China and the U.S. - serve to illustrate the universality of this multilevel governance framework and its value as an analytical tool. The focus of this piece is environmental management, but the goal is to put forth a generalizable concept of multilevel governance.

Using this five-part framework, this paper shows how both countries, in seeking to reform environmental governance, have moved to a more multilevel approach. The U.S., which adopted a top-down, command-and-control system in the 1960s and 1970s, now faces more complex challenges requiring local knowledge and buy-in (Homsy \& Warner, 2013). In contrast, China has promoted decentralization and relegated environmental protection to the local level where economic development priorities overwhelm other concerns (Kostka \& Mol, 2013; Ran, 2013). The Chinese government's inability to enforce goals and regulations has led to more central leadership and sanctioning recently, but the situation still lacks a comprehensive multilevel approach (Kostka, 2016; Liu, Lo, Zhan, \& Wang, 2015). Recent political shifts in both countries will test the resiliency going forward of different aspects of a multilevel governance framework. 


\section{Approaches to Sustainability Governance}

Scholars have long debated the appropriate governance framework for common-pool resources. In the 1970s and 80s, with limited experience regulating the world's growing pollution problems, the general understanding for common-pool resource challenges was that management required a top-down, command-and-control approach often involving a central authority, such as a national government (Fiorino, 2006). In the United States, national regulations and subsidies to lower level governments resulted in a much cleaner environment despite a rapidly growing economy (Andrews, 2006). However, this approach does not work well with complex problems (Fiorino, 2006; Kettl, 2002). When top-down policymakers do not engage local stakeholders, the result may be local people "biting back in unexpected ways" that threaten to undermine initiatives (Leach, 2008, p. 1784). Central mandates are often command and control regulations, which work best on environmental problems with easily identifiable pollution sources and relatively straightforward solutions. Such mandates provide little flexibility for adjusting regulations to local circumstances (Kostka, 2016; Mazmanian \& Kraft, 1999) often resulting in the imposition of "naïve" one-size-fits-all solutions (Ostrom, 2010b, p. 363)).

More recently the focus has shifted to the importance of local solutions to regional and global commons problems. Developed as a theory of small-scale, common-pool resource management, this polycentric approach has been applied to commons issues of a larger scale (Ostrom, 2010a). It emphasizes development of local solutions to fit local problems (Nagendra \& Ostrom, 2012), which can create space for inter-local dialog, ensure redundancy of potential solutions, and increase accountability (Sovacool, 2011). Local approaches can also ensure local compliance (Davies \& Mazurek, 1998) and encourage local policy innovation (Lutsey \& 
Sperling, 2008). However, a decentralized approach has collective action drawbacks including negative externalities, spillovers, regional inequity and capacity constraints (Feiock, 2013). Uncoordinated policies can create inconsistent and expensive regulations, incentives, or programs across local governments (Rees \& Hossain, 2010; Salkin \& Ostrow, 2008).

An emerging literature argues for multilevel governance as a better framework for environmental sustainability and other regional or commons challenges (Balme \& Qi, 2014; Bulkeley, 2010; Homsy \& Warner, 2013). In particular, the failure of international climate change processes, such as the Kyoto Protocol, has sparked calls for more experimental approaches to governing commons issues (Keohane \& Victor, 2015). Researchers and practitioners maintain that sustainability involves the intersection of environmental, social, and economic issues, as well as requires actors to break through both functional and geographic silos to address the complexity of real world challenges. Jurisdictional mismatch of authority and responsibility across levels of government hinders environmental protection efforts by wasting resources, hampering innovation, and reducing regulatory effectiveness (Adler, 2005; Liu et al., 2015; Qi \& Zhang, 2014). Therefore, solving sustainability problems requires more systematic, multisector, and multilevel approaches (Homsy, 2018a; Sharma \& Kearins, 2011). Multilevel governance has also been a framework through which scholars have examined other topics including migration policy, aboriginal self-governance, and smoking cessation policy (Marti, 2018; Mavrot \& Sager, 2016; Rodon, 2017).

\section{Components of a Multilevel Governance Framework}

Scholars first employed multilevel governance as a way to analyze the European Union's relationship to its member states (Bulkeley \& Betsill, 2003). It is usually described as engaging 
multiple tiers of government, not unlike cooperative federalism through which states act as agents of federal policy in the U.S. (Fischman, 2005). However, in a multilevel governance framework, cities not only interact with regional and national governments through a hierarchical structure, but also coordinate with each other and with non-state actors to achieve sustainability (Bulkeley \& Betsill, 2005).

This paper proposes a five-component framework for multilevel governance, which integrates hierarchical and horizontal interactions. The components are the coordinating and sanctioning role of a central authority, engagement of civil society, co-production of knowledge, capacity provision, and framing of co-benefits.

- Co-production of knowledge vertically and horizontally so that local knowledge becomes part of the discourse in partnership with centralized policymakers and technical analysts (Funtowicz \& Ravetz, 1993; Homsy \& Warner, 2013). Such engagement identifies actors missing from knowledge generation and policy creation processes (Corburn, 2009). Over time, as expectations and commitments are met, trust is built among officials, who start to understand the positions and values of other actors, which can lead to prioritizing sustainability and more effective policy implementation (Laurian, Walker, \& Crawford, 2017).

- Framing of co-benefits. Local governments may undertake environmental actions when there are co-benefits - for example, reduction in energy costs (Svara, Read, \& Moulder, 2011), increased public health (Bloomberg \& Aggarwala, 2008), or job production (Homsy, 2018b; Kostka \& Hobbs, 2013). Such reframing of a commons problem can counter negative political attitudes and build consensus (Hawkins, Kwon, \& Bae, 2016) and stimulate local action because residents see concerns as important to them (Metz \& Below, 2009). 
- Engagement of civil society. Citizen voice can motivate government action. Citizen scientists often monitor environmental issues and collaborate with institutions, such as universities, to advocate for change (Conrad \& Hilchey, 2010). Citizens appointed to government committees push local environmental action in the U.S. (Homsy \& Warner, 2015). Cities with wealthier and more educated residents participate in interest groups around policy discussions and boost sustainability outcomes (Cruz \& Smith, 2016). In China, local activists have had some success countering top-down, non-consultative decisions, such as dams, garbage incinerators, and chemical plants (Johnson, 2013; Mertha, 2008).

- Provision of capacity. Governments need technical, professional, and financial resources to act. As problems grow more complex, such as in the case of sustainability, more resources are needed (Honadle, 2001). Multilevel governance requires that actors have the ability to mobilize the resources and capacity that many local governments lack (Koontz \& Newig, 2014; Liu et al., 2015).

- Sanctioning and coordinating authority. Multilevel governance needs a sanctioning and coordinating power to help frame the problem, determine the distribution of externalities, provide organizational structures, and enforce solutions on decentralized actors (Hawkins et al., 2016; Homsy \& Warner, 2013). This authority provides a coordinating role to encourage local innovation and to engage multiple actors. This mechanism differs from the top-down system in which a dominant central power not only controls the science of sustainability, but also dictates policy goals and solutions. Rather, in a multilevel governance system, power is shared across the network. Still, the rule of law must exist and the central authority must have the power to sanction those that do not maintain their commitments to the goals of the framework. Inaction must have a cost (Keohane \& Victor, 2015). Milward and Provan 
(2000) in their work on the hollow state, acknowledge the need for a strong center to ensure network actors coordinate to meet public policy goals.

This article compares environmental governance in two case examples from countries with drastically different political, economic, and social contexts: Rouge River watershed management in the U.S. and Beijing-Hebei-Tianjin air quality action in China. The data for this analysis come from primary documents (such as policy documents issued by central and local government agencies, plans and project archives, technical reports, conference minutes, and speeches made by government officials) as well as secondary documents (such as news reports, journal articles, and books analyzing actions in the regions). The findings illustrate how the U.S. and China have moved from opposite positions - from the top-down federal governance in U.S. environmental action and from the decentralized governance in China - to a more multilevel approach. By adopting a most-different comparison (Seawright \& Gerring, 2008), the article demonstrates that, even in disparate cases, multilevel governance provides a better analytical framework to understand the success or failure of sustainability outcomes.

\section{Case Examples: Divergent Analyses of Multilevel Governance}

\section{The Rouge River Watershed in the United States}

The case of the Rouge River watershed in the State of Michigan shows the limits of both top-down and bottom-up approaches and the potential of multilevel governance when facing a complex problem such as non-point source pollution. The watershed consists of four waterways: a main stream, which is 71 kilometers in length and three major branches. All of the water 
eventually flows into Lake Erie via the the Detroit River. The 1210-square kilometer Rouge River watershed has more than 1.5 million people living in 48 communities.

Until the 1960s, millions of gallons of oil and petroleum pollutants per year were dumped directly into the Rouge River by auto companies; waste from steel mills turned the water orange; and at one point, the river caught fire. The Rouge River became the most polluted in Michigan and one of the worst in the nation (Hartig, 2010). This was common in the United States as states and localities struggled to contain pollution in a decentralized manner (Fiorino, 2006). Local politics, the unwillingness to incur costs, and a lack of concern about other municipalities hindered cleanup, with cities dumping raw sewage into the waterways from which downstream neighborhoods drew drinking water (Holloway, Strickland, Gerrard, \& Firger, 2014). Wellconnected industry officials undercut decentralized regulatory efforts by threatening to relocate operations (Andreen, 2003b).

Frustrated by the lack of progress, in 1972 the U.S. Congress passed the Clean Water Act, which imposed federal standards on industrial polluters by requiring that they adhere to uniform pollution control standards regardless of where in the nation the facility was located or what kind of stream received its waste. To ease enforcement, the new permit system imposed strict technology requirements that constituted compliance, rather than regulators having to link a particular pollutant with a specific polluter (Andreen, 2003a). As a result, levels of toxic pollution in the Rouge River watershed dropped dramatically (Beam \& Braunscheidel, 1998) and industrial discharges were no longer a major concern (Cave, 2003).

As point source pollution decreased, a more complex problem became more prominent: non-point source pollution including runoff from farm fertilizers, pesticides, and animal waste as well as nutrients and pesticides from lawns, eroded soil from development projects, and oils and 
salts from streets (Lyon \& Stein, 2009). Local land use controls and the diversity of local circumstance made effective federal regulation difficult (Andreen, 2004; Holloway et al., 2014). In the Rouge River watershed, despite the reduction in industrial effluent, stormwater runoff still accounted for two-thirds of the heavy metal lead entering the river; and hundreds of millions of gallons of raw sewage flowed into the waterway every year (U.S. GAO, 1988). To tackle this diffuse, nonpoint source pollution, the U.S. Environmental Protection Agency shifted to a multilevel approach in the region that enlisted the support of regulated communities (U.S. EPA, 2003). Using the threat of an expensive federal court order that would create a watershed-wide stormwater authority to direct river cleanup, the federal government pushed municipalities to sign on to a collaborative effort, the Rouge River National Wet Weather Demonstration Project (Cave, 2003).

The watershed was divided into seven sub-areas with an advisory group responsible for each. Sub-watersheds varied in terms of residential and commercial density as well as the amount of impervious surface. The regional structure allowed community differences to factor into local remedies. Dense urban areas might have to build infrastructure to control contaminated stormwater, while suburban or rural places could focus on reducing nutrient runoff from lawns or farms. A steering committee coordinated the work across the entire watershed (U.S. EPA, 2007). Over the years, the federal government spent hundreds of millions of dollars funding different watershed projects (Alliance of Rouge Communities, 2011; Copeland, 2012, 2014).

In 2006, the steering committee evolved into a non-profit organization, the Alliance of Rouge Communities, which consists of 36 municipalities, three counties, and other organizations (Alliance of Rouge Communities, n.d.). The Alliance coordinates stormwater management, pollution reduction, and recreational opportunities (Alliance of Rouge Communities, 2011). 
From the beginning, the project involved extensive outreach to residents and business owners to increase watershed awareness, prevent pollution, and enlist local knowledge (Powell, Ball, \& Reaume, 2000). The result is a much cleaner river. The flow of polluted stormwater into the river has been reduced 90 to 100 percent, and the discharge of toxic chemicals has dropped to acceptable levels. People can consume the fish, wildlife populations are growing, and dissolved oxygen levels have risen (Hartig, 2010).

Such collaboration represents an increasingly common approach to environmental governance in the United States. In most of these situations, action is a response to federal regulations with money coming from either federal or state coffers (Koontz \& Newig, 2014; Margerum \& Robinson, 2015; Robinson, Margerum, Koontz, Moseley, \& Lurie, 2011). Pledges by the Trump administration to roll back federal regulations and cut funding of environmental protection, threaten to undermine the role of the national government as the sanctioning and coordinating authority, as well as the provider of capacity. The next few years will test the resiliency of multilevel governance as national level support declines.

\section{China's Beijing-Tianjin-Hebei Air Management Challenge}

Recent efforts to combat air pollution in the Beijing-Tianjin-Hebei urban agglomeration show some early of progress in coordinating inter-jurisdictional environmental efforts. The region encompasses two provincial-level municipalities (Beijing, the capital city, and Tianjin)

and one province (Hebei), with a total population of over 100 million people and a total land area of 216,000 square kilometers. In the fall of 2011, consecutive days of heavy smog in northern China shocked the public and turned into a global embarrassment. The choking air pollution worsened in the following years. The smog disaster in January 2013 affected about 1.43 million 
square kilometers of the nation and more than 850 million people (Beijing Municipal Environmental Protection Bureau, 2014). Cities in the Beijing-Tianjin-Hebei Region consistently ranked as the most polluted with the average annual concentration of fine particulate matter (PM2.5) reaching more than three times the national standard and ten times World Health Organization standard (Beijing Municipal Environmental Protection Bureau, 2014). Sources of air pollution vary by place with serious cross-border spillovers. Automobiles account for 31.1 percent of the fine particulate matter in Beijing, while dust and coal mining account for the biggest share in Tianjin and Hebei respectively. About one-third of fine particulate matter in Beijing comes from metal smelting and coal burning in the neighboring places, especially Hebei Province (Beijing Municipal Environmental Protection Bureau, 2015).

Efforts to contain such pollution in China have been stymied by fragmented governance in which local officials have been fiscally and politically incentivized to focus on short-term economic growth. The first national Environmental Protection Law, passed in 1989, was not enforced at all (van Rooij, 2006). The central government environmental regulatory agency - the State Environmental Protection Agency, called the Ministry of Environmental Protection (MEP) until 2008 - remained weak and lacked the power to sanction provinces and local governments. Local environmental protection bureaus receive guidance and directives from the MEP, but their budgets, personnel decisions, and political direction come from their local governments, which are reluctant or unable to enforce national regulations. The fragmentation undercut efforts to incentivize, coordinate, or sanction local government behavior in environmental regulation (Ran, 2013), leading to great regional disparity in local responses to ecological challenges (Mol \& Carter, 2006). 
Starting in the late 1990s, the central government began including numeric targets for energy saving and pollutant reduction in the Eleventh Five-Year Plan (2006-2010), with more sustainability goals included in the Twelfth Five-Year Plan (2011-2015) (Kostka \& Hobbs, 2012; Liu et al., 2015). The central government also sought to intensify local compliance by mobilizing financial and administrative resources, empowering national and local environmental protection bureaus, and increasing political pressure on local leaders (Liu et al., 2015). This effort achieved some short-term results, but was not effective in addressing complex problems. The top-down measures imposed one national remedy for all localities and disregarded differences in geography and disparities in level of economic development as well as inequalities in local knowledge and capacity, while leading to a "command without control" situation in environmental governance (Kostka, 2016, p. 58).

In September 2013, the national State Council (2013) adopted an aggressive and comprehensive air quality action plan. The document specified five-year targets for air pollution reduction for all cities, including a 25 percent reduction of fine particular matter across the Beijing-Tianjin-Hebei Region and called for regional coordination on air pollution reduction. However, breaking administrative boundaries turned out to be more difficult than expected. While MEP required each province to create local implementation plans, none of these local documents mentioned regional collaboration or accounted for regional spillovers (Beijing Municipal Government, 2013; Hebei Provincial Government, 2013; Tianjin Municipal Government, 2013). Policy measures focused on hierarchical accountability but not on regional inequality problems across localities or on framing the co-benefits of air pollution reduction.

In 2014 President Xi Jinping called a meeting of provincial leaders and made a series of speeches urging a coordinated program to address both individual municipal problems as well as 
commons challenges facing the region. Premier Li Keqiang declared a "war on pollution" as part of the leadership's commitment at the 2014 annual meeting of National People's Congress, China's national legislative body (Larson, 2014). The direct intervention of top leaders strengthened the central authority to enforce the air quality goals, but also sought to provide coordination, capacity, and information for local governments. The State Council established the Steering Group for Air Pollution Control for the region, with members from provincial and local authorities as well as environment-related ministries at the national level (Wang et al., 2018). The central government provided billions of yuan in funding for the regional effort with municipalities in the poorer Hebei province receiving preferential allocation of the funds.

The direct intervention of top leaders gave the MEP the political leverage to enforce rules and to sanction local leaders who failed to comply. The MEP now works with the Communist Party's Organization Department, which is in charge of officials' performance evaluation and promotion, to increase the pressure on these local leaders. In 2017, the central government ordered tens of thousands of factories to cease operations in a reported effort to control pollution (Hornby \& Hancock, 2017; Koh, 2017). The MEP also sought to hold local leaders accountable to their constituents by making environmental information more transparent. Traditionally, negative environmental information in China is kept from public release, especially if it impacts business development (W. Li \& Li, 2012). In 2012, the MEP started to publicly release an hourly air pollution index. By November 2014 citizens in every city could track their air quality via a website or smart phone, which enabled citizens to voice their concerns and become engaged in environmental governance.

Provincial and local governments began to undertake bottom-up initiatives for joint actions and information sharing - at least on paper. In January 2015, Tianjin passed the Local 
Act of Air Pollution Control, in which a full chapter was devoted to collaboration with Beijing and Hebei (Tianjin People's Congress, 2015). Based on bilateral agreements, Hebei Province received funds from Beijing and Tian (860 million yuan in 2015 and 900 million yuan in 2016) in support of collaborative measures to reduce air pollution in the region. The joint efforts expanded to address regional inequality in economic development and public service provision. The mayor of Beijing, speaking at the local People's Congress in 2015, noted that his city would "continue the joint work with Tianjin and Hebei to [...] develop the mechanism for shared benefit and shared responsibility in economic development and energy saving and emission reduction" (Zhu \& Yu, 2015, p. 6). Hebei Provincial Government similarly declared its commitment to "assist its prefectural level cities to collaborate with Beijing and Tianjin" (Hebei Provincial Steering Group, 2015, p. 18). At the same time, officials in the Beijing-Tianjin-Hebei region announced the formation of an agency to clean the air by taking measures such as setting regional standards and preventing non-compliant factories from moving from one city to the next (VOA, 2017).

\section{Discussion: The Emergence of a Multilevel Framework}

The case examples illustrate the importance of a multilevel governance approach in both countries. As shown by the Rouge River cleanup, the United States moved from a top-down, command-and-control system of environmental governance to a multilevel approach more suited to nonpoint sources of pollution. In China, the national government has tried to move from a decentralized approach to a multilevel effort that combines local action with national level sanctions, information and capacity support to encourage more local enforcement, and when that fails, national enforcement, which was lacking before (Balme \& Qi, 2014; Kostka \& Hobbs, 
2013; Liu et al., 2015). The Rouge River case in the U.S. illustrates a success of multilevel governance; the Chinese case illustrates the manner in which a multilevel approach falls short as the nation struggles to balance central power and local initiative.

In multilevel governance, the co-production of knowledge and policy occurs both horizontally and vertically. Federal officials in the U.S. recognized that different parts of the Rouge River Watershed required different cleanup efforts. The education and outreach efforts revealed that expensive, engineered pollution controls would be needed in more industrialized and densely populated areas, while less intense efforts were appropriate elsewhere. The knowledge of local residents helps target problem spots, such as particular businesses or farms, and find specific and effective solutions. The result in the U.S. has been a locally tailored cleanup effort, made more effective because every municipality participated under the EPA agreement. In China, the air pollution challenges are both from heavy industry and non-point sources. However, China is still struggling to build the avenues of co-production and cooperation that would allow officials to address social and economic inequities (especially in outlying, industrial cities in Hebei province) and national support for sanctions also is needed to force both industry and local government compliance with national rules (Kostka, 2016).

Civil society in the U.S. has always played an important role in environmental protection efforts. In addition to local leaders, membership in each sub-watershed council of the Rouge River includes community residents and other stakeholders - and the effort includes an extensive public outreach program. Management duties of the cleanup have moved to a non-profit organization, Alliance of Rouge Communities, whose main members are local governments, and whose associate members include local research and educational institutions and environmental groups, which provide technical capacity and political support for the effort. These organizations 
also have an independent right to sue and use the courts as ultimate arbiter. In contrast, China's environmental governance largely operates within the administrative system and with limited outside check-and-balance (Chi, Xu, \& Xue, 2014; Kostka \& Mol, 2013), which undermines the enforcement of environmental regulations. Citizen participation has been limited to information transparency about air pollution levels to raise public awareness, or tightly-controlled public hearings over environmental impacts of specific projects. The information disclosure act has had some limited impact with citizens requesting environmental information and pushing local officials to enforce anti-pollution regulations (van Rooij, Zhu, Na, \& Qiliang, 2017). The new Environmental Protection Law, passed in 2014, allowed individual citizens and NGOs to seek legal remedies in pollution cases. The first case, decided in August 2016, found against the polluter and marked a first step toward more direct involvement of the civil society, though how this may transform China's environmental governance remains to be seen.

The framing of co-benefits component of the multilevel governance framework is also important. In the U.S., the local cleanup efforts were closely tied to other economic benefits, especially around the recreation and tourism industries, which built political support among a wide variety of constituents. In China, local governments have tried to tie national air quality targets to reduced traffic congestion locally, industrial sector upgrades, and healthy quality of life gains. National and local officials recognize the need to address the regional inequality of economic development, but regional collaboration remains in its very early stages.

The need for a coordinating and sanctioning authority in a multilevel governance framework is illustrated by the different results in the two cases. In the U.S. before the federal government intervened, local governments in the Rouge River Watershed were unable to address the externalities, which neighbors imposed on each other. The EPA's approach brought scores of 
communities together and enabled each to understand the challenges faced by others within their sub-watershed and across the entire region. The result has been an effective, locally tailored cleanup effort, which would have been less successful if every municipality had not participated or if the EPA had simply imposed a single solution for all situations. In China, after a push by the central government, local leaders developed the language for regional collaboration and embraced it in local laws and public statements. For example, Beijing has committed resources to help poorer neighbors in Hebei, although air pollution from Hebei's factories continues to affect residents across the region. But enforcement of rules is uneven with greater pollution reductions in the larger, more urban, and coastal cities and regions while poorer and more inland places do not have the resources or political will to take anti-pollution steps. In some urban areas, the increased centralization has resulted in many anti-corruption crackdowns, but the question remains about whether these will serve as a deterrent (van Rooij et al., 2017) or if the government will simply put factories in the hands of other, more favored polluters.

Capacity is also a critical component of the multilevel framework. The U.S. federal government has spent hundreds of millions of dollars on the Rouge River clean up - something that state and local authorities would not have been able to do on their own. Similarly, the Chinese national government set up a fund to support local efforts, with preference given to poorer municipalities with weaker fiscal capacity. The central government has also added more staff to the local environmental protection bureaus which are having a mixed effect on getting past the local protectionism of industries and moving towards greater emphasis on cleanup (van Rooij et al., 2017).

Finally, the two cases illustrate the important role of sanctioning power in a multilevel governance system. In the U.S., the threat of an expensive lawsuit by the U.S. federal 
government brought local players to the table and encouraged the collaboration to take place. At one time or another all three branches of the U.S. national government have exercised authority and helped ensure compliance with environmental rules. In China, the absence of environmental protection as a central government priority has hindered the development of environmental solutions and allowed industry and local governments to ignore the growing air pollution problems despite the adoption of national regulations. When the top leaders of the Communist Party decided to use their political power, the central authority was able to bring together local leaders to start to collaborate on pollution and other common issues in the Beijing-Tianjin-Hebei Region. However, the central authority has primarily relied on the Communist Party's political accountability system, which ties implementation with local officials' career advancement, to enforce local compliance with national environmental programs, or more recently, draconian crackdowns on local governments and local factories. Rule of law and access to the judicial system is underdeveloped. Without the full set of multilevel governance components in place, especially legal authority, capacity and norms of civic engagement, there is little way for local governments and citizens to continue to pursue environmental protection if the national authority changes priorities.

\section{Conclusion}

This paper has used a multilevel governance framework to analyze two complex and radically different sustainability issues in environmental governance. The framework includes five elements: framing of co-benefits, engagement of civil society, the co-production of knowledge, the provision of capacity, and the power to sanction and coordinate. The U.S., at least in the case of the Rouge River, has successfully implemented a multilevel approach that 
embraces and illustrates the way the components of this framework can result in positive policy outcomes. The Chinese government is just starting to develop a multilevel governance framework that balances central authority with local knowledge and regional collaboration among municipal officials. China's experiments with reframing co-benefits and engaging the public - two key components linked to success in the US Rouge River case - are still nascent. Two different cleanup outcomes have resulted so far. The water quality in the Rouge River has dramatically improved, while the air quality in the Beijing-Tianjin-Hebei region remains unhealthy, though there are some early signs of improvement. Despite the immense differences in the size, population, and pollution problems in the regions, both cases illustrate the analytical utility of a multilevel governance framework.

An important question moving forward is whether a multilevel governance framework provides resiliency by building local capacity, which can be used to hold higher levels of government accountable. Recently in the United States, the administration of President Donald Trump has begun to reduce the role of the federal government in areas of environmental protection and enforcement. Over time, the multilevel framework, through the co-production of knowledge and the framing of co-benefits, may have instilled norms and values at lower levels that cause state and local government and civil society groups to push back against the erosion of federal government support for environmental protection (See, for example Tabuchi \& Fountain, 2017.). Does the sharing of power within a multilevel system provide lower level entities an avenue of upward sanctioning power to push the federal government to continue enforcing environmental laws? In China, President Xi has started to sanction local governments and polluting factories that previously were allowed to avoid environmental enforcement (Xiangwei, 2017). There is evidence that Chinese localities and their citizens are beginning to embrace 
values of cleaner air (Kuhn, 2017). But without legal avenues of recourse for local entities, it remains to be seen whether local governments and citizens will be engaged and empowered to continue clean-up efforts if national government priorities change.

A multilevel governance framework provides researchers with an analytical structure that potentially explains the manner in which top-down and bottom-up governance can come together. Future research can test its application in other circumstances both around issues of sustainability and in other vertically and horizontally integrated service provision efforts. In practice, this framework enables policymakers to understand the broad range of components needed to tackle regional and global commons issues.

\section{References}

Adler, J. (2005). Jurisdictional Mismatch in Environmental Federalism. New York University Environmental Law Journal, 14, 130-178.

Alcantara, C., \& Nelles, J. (2014). Indigenous Peoples and the State in Settler Societies: Toward a More Robust Definition of Multilevel Governance. Publius: The Journal of Federalism, 44(1), 183204. https://doi.org/10.1093/publius/pjt013

Alliance of Rouge Communities. (2011). Rouge River National Wet Weather Demonstration Project 2011 Progress Report - Executive Summary. Wayne County, MI.

Alliance of Rouge Communities. (n.d.). ARC - History. Retrieved April 21, 2016, from http://www.allianceofrougecommunities.com/history.html

Andersson, K. P., \& Ostrom, E. (2008). Analyzing decentralized resource regimes from a polycentric perspective. Policy Sciences, 41(1), 71-93. https://doi.org/10.1007/s11077-007-9055-6

Andreen, W. L. (2003a). The Evolution of Water Pollution Control in the United States - State, Local, and Federal Efforts, 1789-1972: Part 1. Stanford Environmental Law Journal, 22, 145-200. 
Andreen, W. L. (2003b). The Evolution of Water Pollution Control in the United States-State, Local, and Federal Efforts, 1789-1972: Part II. Stanford Environmental Law Journal, 22(215-294).

Andreen, W. L. (2004). Water Quality Today-Has the Clean Water Act Been a Success? Alabama Law Review, 55, 537-593.

Andrews, R. N. L. (2006). Managing the Environment, Managing Ourselves: A History of American Environmental Policy. New Haven, CT: Yale University Press.

Balme, R., \& Qi, Y. (2014, June 5). Multi-Level Governance and the Environment: Intergovernmental Relations and Innovation in Environmental Policy. Environmental Policy \& Governance, pp. $147-154$.

Beam, J. D., \& Braunscheidel, J. J. (1998). Rouge River Assessment (Fisheries Special Report No. 22). Lansing, MI: Michigan Department of Natural Resources.

Beijing Municipal Environmental Protection Bureau. (2014). MEP Releasing the 2013 Air Quality Report for Major Regions and 74 Cities. Beijing: Beijing Municipal Government. Retrieved from http://www.mep.gov.cn/gkml/hbb/qt/201403/t20140325_269648.htm

Beijing Municipal Environmental Protection Bureau. (2015). Beijing Environmental Statement 2014. Beijing: Beijing Municipal Government. Retrieved from http://www.bjepb.gov.cn/bjepb/resource/cms/2015/04/2015041609380279715.pdf Beijing Municipal Government. (2013). Beijing 2013-2017 Clean Air Action Plan. Beijing: Beijing Municipal Government. Retrieved from http://zhengwu.beijing.gov.cn/ghxx/qtgh/t1324558.htm

Bloomberg, M. R., \& Aggarwala, R. T. (2008). Think Locally, Act Globally: How Curbing Global Warming Emissions Can Improve Local Public Health. American Journal of Preventive Medicine, 35(5), 414-423. https://doi.org/16/j.amepre.2008.08.029

Bulkeley, H. (2010). Cities and the Governing of Climate Change. Annual Review of Environment and Resources, 35(1), 229-253. https://doi.org/10.1146/annurev-environ-072809-101747

Bulkeley, H., \& Betsill, M. (2003). Cities and climate change: urban sustainability and global environmental governance. London: Routledge. 
Bulkeley, H., \& Betsill, M. (2005). Rethinking Sustainable Cities: Multilevel Governance and the "Urban" Politics of Climate Change. Environmental Politics, 14(1), 42-63. https://doi.org/10.1080/0964401042000310178

Caponio, T., \& Jones-Correa, M. (2017). Theorising migration policy in multilevel states: the multilevel governance perspective. Journal of Ethnic and Migration Studies, O(0), 1-16. https://doi.org/10.1080/1369183X.2017.1341705

Cave, K. A. (2003). Evaluation of Michigan Watershed-Based Storm Water Discharge Permit and Summary of Implementation in the Rouge River Watershed. Detroit: Wayne County Department of Environment. Retrieved from http://www.michigan.gov/documents/deq/wb-stormwaterWayneRougeEval_248401_7.pdf

Chi, C. S. F., Xu, J., \& Xue, L. (2014). Public participation in environmental impact assessment for public projects: a case of non-participation. Journal of Environmental Planning and Management, 57(9), 1422-1440. https://doi.org/10.1080/09640568.2013.810550

Conrad, C. C., \& Hilchey, K. G. (2010). A review of citizen science and community-based environmental monitoring: issues and opportunities. Environmental Monitoring and Assessment, 176(1-4), 273291. https://doi.org/10.1007/s10661-010-1582-5

Copeland, C. (2012). Water Infrastructure Financing: History of EPA Appropriations. Washington, DC: Congressional Research Service. Retrieved from https://www.fas.org/sgp/crs/misc/96-647.pdf

Copeland, C. (2014). Water infrastructure projects designated in EPA appropriations: Trends and policy implications. Washington, DC: Congressional Research Service. Retrieved from http://nationalaglawcenter.org/wp-content/uploads/assets/crs/RL32201.pdf

Corburn, J. (2009). Cities, Climate Change and Urban Heat Island Mitigation: Localising Global Environmental Science. Urban Studies, 46(2), 413-427. https://doi.org/10.1177/0042098008099361 
Cruz, E. E. R. de la, \& Smith, H. J. M. (2016). What Encourages Cities to Become Sustainable?

Measuring the Effectiveness of Implementing Local Adaptation Policies. International Journal of Public Administration, 39(10), 718-728. https://doi.org/10.1080/01900692.2015.1023445

Dale, A., Burch, S., Robinson, J., \& Strashok, C. (2018). Multilevel Governance of Sustainability Transitions in Canada: Policy Alignment, Innovation, and Evaluation. In Climate Change in Cities (pp. 343-358). Springer, Cham. https://doi.org/10.1007/978-3-319-65003-6_17

Davies, J. C., \& Mazurek, J. (1998). Pollution Control in the United States: Evaluating the System. Washington, DC: Resources for the Future.

Feiock, R. C. (2013). The Institutional Collective Action Framework. Policy Studies Journal, 41(3), 397425. https://doi.org/10.1111/psj.12023

Fiorino, D. J. (2006). The New Environmental Regulation. Cambridge, MA: The MIT Press.

Fiorino, D. J. (2010). Sustainability as a Conceptual Focus for Public Administration. Public Administration Review, 70(Special issue), s78-s88.

Fischman, R. L. (2005). Cooperative Federalism and Natural Resources Law. New York University Environmental Law Journal, 14, 179.

Funtowicz, S. O., \& Ravetz, J. R. (1993). Science for the post-normal age. Futures, 25(7), 739-755. https://doi.org/10.1016/0016-3287(93)90022-L

Hartig, J. H. (2010). Burning Rivers: The Revival of Four Urban-Industrial Rivers that Caught on Fire. Burlington, Ontario: Ecovision World Monograph Series.

Hawkins, C. V., Kwon, S.-W., \& Bae, J. (2016). Balance Between Local Economic Development and Environmental Sustainability: A Multi-level Governance Perspective. International Journal of Public Administration, 39(11), 803-811. https://doi.org/10.1080/01900692.2015.1035787

Hebei Provincial Government. (2013). Hebei Province Implementation Plan for Air Pollution Prevention and Control Action Plan. Retrieved from http://www.hebhb.gov.cn/ztbd/hbdqwrfz/xgwj/201309/t20130925_38906.html 
Hebei Provincial Steering Group. (2015). Notice on the 2015 Key Tasks for Hebei Province Air Pollution Prevention and Control (No. Document No. HB-ASP-2015-61). Hebei Provincial Steering Group of Air Pollution (General Office). Retrieved from http://www.hb12369.net:8080/pub/root8/auto454/201510/W020151029522569218173.pdf

Holloway, C. F., Strickland, C. H., Gerrard, M. B., \& Firger, D. M. (2014). Solving the CSO Conundrum: Green Infrastructure and the Unfulfilled Promise of Federal-Municipal Cooperation. Harvard Environmental Law Review, 38, 335-369.

Homsy, G. C. (2018a). Size, Sustainability, and Urban Climate Planning in a Multilevel Governance Framework. In S. Hughes, E. K. Chu, \& S. G. Mason (Eds.), Climate Change in Cities (pp. 1938). Cham, Switzerland: Springer. https://doi.org/10.1007/978-3-319-65003-6_2

Homsy, G. C. (2018b). Unlikely pioneers: creative climate change policymaking in smaller U.S. cities. Journal of Environmental Studies and Sciences, 8(2), 121-131. https://doi.org/10.1007/s13412018-0483-8

Homsy, G. C., \& Warner, M. E. (2013). Climate Change and the Co-Production of Knowledge and Policy in Rural USA Communities. Sociologia Ruralis, 53(3), 291-310. https://doi.org/10.1111/soru.12013

Homsy, G. C., \& Warner, M. E. (2015). Cities and Sustainability: Polycentric Action and Multilevel Governance. Urban Affairs Review, 51(1), 46-73. https://doi.org/10.1177/1078087414530545

Honadle, B. W. (2001). Theoretical and practical issues of local government capacity in an era of devolution. Journal of Regional Analysis and Policy, 31(1), 77-90.

Hornby, L., \& Hancock, T. (2017, October 12). China targets pollution on eve of Xi Jinping's second term. Retrieved November 2, 2017, from https://www.ft.com/content/f48c9674-ae68-11e7-beba5521c713abf4

Johnson, T. (2013). The Politics of Waste Incineration in Beijing: The Limits of a Top-Down Approach? Journal of Environmental Policy \& Planning, 15(1), 109-128. https://doi.org/10.1080/1523908X.2012.752183 
Keohane, R. O., \& Victor, D. G. (2015). After the failure of top- down mandates: The role of experimental governance in climate change policy. In S. Barrett, C. Carraro, \& J. de Melo (Eds.), Towards a Workable and Effective Climate Regime (pp. 201-212). London: CEPR Press.

Kettl, D. F. (2002). The transformation of governance: public administration for twenty-first century America. Baltimore, MD: John Hopkins University Press.

Koh, J. (2017, October 13). The rise and rise of Xi Jinping [Channel NewsAsia]. Retrieved November 2, 2017, from http://www.channelnewsasia.com/news/asiapacific/the-rise-and-rise-of-xi-jinping9307354

Koontz, T. M., \& Newig, J. (2014). From Planning to Implementation: Top-Down and Bottom-Up Approaches for Collaborative Watershed Management. Policy Studies Journal, 42(3), 416-442. https://doi.org/10.1111/psj.12067

Kostka, G. (2016). Command without control: The case of China's environmental target system. Regulation \& Governance, 10(1), 58-74. https://doi.org/10.1111/rego.12082

Kostka, G., \& Hobbs, W. (2012). Local energy efficiency policy implementation in China: Bridging the gap between national priorities and local interests. The China Quarterly, 211, 765-785.

Kostka, G., \& Hobbs, W. (2013). Embedded Interests and the Managerial Local State: the political economy of methanol fuel-switching in China. Journal of Contemporary China, 22(80), 204-218.

Kostka, G., \& Mol, A. P. J. (2013). Implementation and Participation in China's Local Environmental Politics: Challenges and Innovations. Journal of Environmental Policy \& Planning, 15(1), 3-16. https://doi.org/10.1080/1523908X.2013.763629

Kuhn, A. (2017, March 2). For Some In China’s Middle Class, Pollution Is Spurring Action [National Public Radio]. Retrieved December 26, 2017, from https://www.npr.org/sections/parallels/2017/03/02/518173670/for-some-in-chinas-middle-classpollution-is-spurring-action

Larson, C. (2014). China Gets Serious About Its Pollutant-Laden Soil. Science, 343(6178), 1415-1416. https://doi.org/10.1126/science.343.6178.1415 
Laurian, L., Walker, M., \& Crawford, J. (2017). Implementing Environmental Sustainability in Local Government: The Impacts of Framing, Agency Culture, and Structure in US Cities and Counties. International Journal of Public Administration, 40(3), 270-283. https://doi.org/10.1080/01900692.2015.1107738

Leach, M. (2008). Pathways to Sustainability in the forest? Misunderstood dynamics and the negotiation of knowledge, power, and policy. Environment and Planning A, 40(8), 1783 - 1795. https://doi.org/10.1068/a40215

Li, H., \& Yi, H. (2014). Multilevel governance and deployment of solar PV panels in U.S. cities. Energy Policy, 69, 19-27. https://doi.org/10.1016/j.enpol.2014.03.006

Li, W., \& Li, D. (2012). Environmental Information Transparency and Implications for Green Growth in China. Public Administration and Development, 32(3), 324-334. https://doi.org/10.1002/pad.1626

Liu, N. N., Lo, C. W.-H., Zhan, X., \& Wang, W. (2015). Campaign-Style Enforcement and Regulatory Compliance. Public Administration Review, 75(1), 85-95. https://doi.org/10.1111/puar.12285

Lutsey, N., \& Sperling, D. (2008). America's bottom-up climate change mitigation policy. Energy Policy, 36(2), 673-685. https://doi.org/10.1016/j.enpol.2007.10.018

Lyon, G. S., \& Stein, E. D. (2009). How effective has the Clean Water Act been at reducing pollutant mass emissions to the Southern California Bight over the past 35 years? Environmental Monitoring and Assessment, 154(1-4), 413-426. https://doi.org/10.1007/s10661-008-0408-1

Margerum, R. D., \& Robinson, C. J. (2015). Collaborative partnerships and the challenges for sustainable water management. Current Opinion in Environmental Sustainability, 12(Supplement C), 53-58. https://doi.org/10.1016/j.cosust.2014.09.003

Marti, G. (2018). The effects of multilevel governance on the rights of migrant domestic workers in Singapore. Journal of Ethnic and Migration Studies, O(0), 1-16. https://doi.org/10.1080/1369183X.2018.1441614 
Mavrot, C., \& Sager, F. (2016). Vertical epistemic communities in multilevel governance. Policy \& Politics. https://doi.org/10.1332/030557316X14788733118252

Mazmanian, D. A., \& Kraft, M. E. (1999). The Three Epochs of the Environmental Movement. In D. A. Mazmanian \& M. E. Kraft (Eds.), Toward Sustainable Communities: Transition and Transformations in Environmental Policy (pp. 3-41). Cambridge, Massachusetts: The MIT Press. Mertha, A. (2008). China's Water Warriors: Citizen Action and Policy Change. Cornell University Press. Metz, D., \& Below, C. (2009). Local land use and climate change policy: summary report from focus groups and interviews with local officials in the Intermountain West (Working Paper No. WP09DM2). Cambridge, MA: Lincoln Institute of Land Policy.

Milward, H. B., \& Provan, K. G. (2000). Governing the Hollow State. Journal of Public Administration Research and Theory, 10(2), 359-379.

Mol, A. P. J., \& Carter, N. T. (2006). China's environmental governance in transition. Environmental Politics, 15(2), 149-170.

Nagendra, H., \& Ostrom, E. (2012). Polycentric governance of multifunctional forested landscapes. International Journal of the Commons, 6(2), 104-133.

Ostrom, E. (2010a). A Long Polycentric Journey. Annual Review of Political Science, 13, 1-23. https://doi.org/10.1146/annurev.polisci.090808.123259

Ostrom, E. (2010b). Nested externalities and polycentric institutions: must we wait for global solutions to climate change before taking actions at other scales? Economic Theory, 49(2), 353-369. https://doi.org/10.1007/s00199-010-0558-6

Powell, J., Ball, Z., \& Reaume, K. (2000). Pubic Involvement Programs that Support Water Quality Management.

Qi, Y., \& Zhang, L. (2014). Local Environmental Enforcement Constrained by Central-Local Relations in China. Environmental Policy \& Governance, 24(3), 216-232. https://doi.org/10.1002/eet.1640 
Ran, R. (2013). Perverse Incentive Structure and Policy Implementation Gap in China's Local Environmental Politics. Journal of Environmental Policy \& Planning, 15(1), 17-39. https://doi.org/10.1080/1523908X.2012.752186

Rees, C. J., \& Hossain, F. (2010). Perspectives on Decentralization and Local Governance in Developing and Transitional Countries. International Journal of Public Administration, 33(12-13), 581-587. https://doi.org/10.1080/01900692.2010.514459

Robinson, C. J., Margerum, R. D., Koontz, T. M., Moseley, C., \& Lurie, S. (2011). Policy-Level Collaboratives for Environmental Management at the Regional Scale: Lessons and Challenges From Australia and the United States. Society \& Natural Resources, 24(8), 849-859. https://doi.org/10.1080/08941920.2010.487848

Rodon, T. (2017). "Working Together": The Dynamics of Multilevel Governance in Nunavut. Arctic Review, 5(2). Retrieved from https://arcticreview.no/index.php/arctic/article/view/1048

Salkin, P. E., \& Ostrow, A. P. (2008). Cooperative Federalism and Wind: A New Framework for Achieving Sustainability. Hofstra Law Review, 37, 1049-1098.

Seawright, J., \& Gerring, J. (2008). Case Selection Techniques in Case Study Research: A Menu of Qualitative and Quantitative Options. Political Research Quarterly, 61(2), 294-308. https://doi.org/10.1177/1065912907313077

Sharma, A., \& Kearins, K. (2011). Interorganizational Collaboration for Regional Sustainability What Happens When Organizational Representatives Come Together? The Journal of Applied Behavioral Science, 47(2), 168-203. https://doi.org/10.1177/0021886310381782

Sovacool, B. K. (2011). An international comparison of four polycentric approaches to climate and energy governance. Energy Policy, 39(6), 3832-3844. https://doi.org/10.1016/j.enpol.2011.04.014

State Council. (2013). Notice on Issuing the Air Pollution Prevention and Control Action Plan (No.

Document No. 2013-37). Retrieved from http://www.gov.cn/zwgk/201309/12/content_2486773.htm 
Stavins, R. N. (2010). The Problem of the Commons: Still Unsettled After 100 Years. National Bureau of Economic Research Working Paper Series, No. 16403. Retrieved from http://www.nber.org/papers/w16403

Svara, J. H., Read, A., \& Moulder, E. (2011). Breaking New Ground: Promoting Environmental and Energy Programs in Local Government (Conserving Energy and the Environment). Washington, DC: IBM Center for the Business of Government.

Tabuchi, H., \& Fountain, H. (2017, June 1). Bucking Trump, These Cities, States and Companies Commit to Paris Accord. The New York Times, p. A12.

Tianjin Municipal Government. (2013). Tianjin Clean Air Action Plan. Tianjin. Retrieved from http://www.tj.gov.cn/zwgk/wjgz/szfwj/201310/t20131009_223397.htm

Tianjin People's Congress. Local Act of Air Pollution Control, Passed at the Third Meeting of the 16th People's Congress of Tianjin $\S(2015)$.

U.S. EPA. (2003). Watershed-Based National Pollutant Discharge Elimination System (NPDES) Permitting Implementation Guidance (No. EPA 833-B-03-004). Washington, DC: U.S. Environmental Protection Agency.

U.S. EPA. (2007). Michigan Statewide Stormwater Permitting (Watershed-Based Permitting Case Study). Washington, DC: U.S. Environmental Protection Agency. Retrieved from http://cfpub.epa.gov/npdes/wqbasedpermitting/wspermitting.cfm

U.S. GAO. (1988). Water Pollution: Efforts to Clean Up Michigan's Rouge River (No. RCED-88-164). Washington, DC: U.S. General Accounting Office.

van Rooij, B. (2006). Implementation of Chinese Environmental Law: Regular Enforcement and Political Campaigns. Development \& Change, 37(1), 57-74. https://doi.org/10.1111/j.0012155X.2006.00469.x

van Rooij, B., Zhu, Q., Na, L., \& Qiliang, W. (2017). Centralizing Trends and Pollution Law Enforcement in China. The China Quarterly, 231, 583-606. https://doi.org/10.1017/S0305741017000935 
VOA. (2017, October 31). China's Beijing-Tianjin-Hebei to Set Up Anti-pollution Body. Retrieved November 2, 2017, from https://www.voanews.com/a/reports-says-china-beiking-tianjin-bebeito-set-up-anto-pollution-body/4094939.html

Wang, L., Zhang, F., Pilot, E., Yu, J., Nie, C., Holdaway, J., ... Krafft, T. (2018). Taking Action on Air Pollution Control in the Beijing-Tianjin-Hebei (BTH) Region: Progress, Challenges and Opportunities. International Journal of Environmental Research and Public Health, 15(2), 306. https://doi.org/10.3390/ijerph15020306

Xiangwei, W. (2017, August 27). Xi faces one of his greatest tests yet: the environment. South China Morning Post. Retrieved from http://www.scmp.com/week-asia/opinion/article/2108336/xi-facesone-his-greatest-tests-yet-chinas-environment

Zhu, J., \& Yu, R. (2015, January 24). Promoting integrated development of Beijing, Tianjin, and Hebei has become a top priority for Beijing this year. People's Daily (Renmin Ribao), p. 6. 